\title{
ŠEHIDSKI (SAMOUBILAČKI) NAPADI U SVJETLU ISLAMSKOG UČENJA
}

\section{Sažetak}

Svaka akcija neminovno dovodi $i$ do reakcije. Maestri savremenog doba su prigrabili vlast $i$ došli na tron upravljanja svijetom, u većini slučajeva, putem laži, obmane i nepravde. Na tom putu ostvarenja tih privilegija nisu se libili pogaziti tuda prava, nanijeti drugom nepravdu, poniženje itd., a kada je bilo potrebno nisu se nimalo libili ni oteti tudu državu i protjerati ili uništi sve njene stanovnike, pa $i$ cijele narode. I ono što je od toga još gore je da je savremeni svijet to prihvatio kao normalno $i$ da su se takve stvari legalizovale $i$ prihvaćale od strane medunarodnih organizacija koje su prvenstveno i uspostavljene da uspostave pravdu, da stanu na stranu slabog protiv nasilnika $i$ da održavaju mir u svijetu. Nažalost, stale su na stranu uzurpatora tudih prava $i$ domovina, nasilnika $i$ otimača $i$ umjesto da štite ljudska prava, one su počele štiti zakone džungle.

Bilo je neminovno onda da takve nepravedne akcije savremenog svijeta dovedu i do različitih reakcija, a jedna od njih je i ova o kojoj želimo pisati i koju želimo istražiti u svjetlu islamskog učenja kao jedinog realnog $i$ objektivnog mjerila za sve što se danas dešava i dogada u svijetu licemjerja, apsurda, nelogičnosti, nepravde i patvorenosti. Dakle, ova studija će pokušati definirati i pojasniti značenje samoubilačkih napada ili šehidskih napada, njihove oblike, pravni status, mišljenja islamskih pravnika o toj pojavi, kritički osvrt na njihove dokaze i konačni stav islama.

Ključne riječi: Napadi, samoubistvo, šehid, mudžahid, akcije, borba, nepravda, pravda, dokaz, mišljenje.

${ }^{1}$ Islamski pedagoški fakultet u Bihaću 


\section{Uvod}

Sintagma samoubilački napad je odskora ušla u savremene svjetske jezike. Kao i sa značenjem riječi demokratija, značenjem ove sintagme, činjena je i još se uvijek čini manipulacija i obmanjivanje. Riječ demokratija se danas najčešće poteže kada velike kolonijalne sile žele da na savremen i legalan način okupiraju neku državu i preuzmu njene prirodne resurse. To je posebno često i općeprihvaćeno kada je riječ o muslimanskim zemljama. Tada se počinje sa propagandom da se, navodno, u tim zemljama čini nasilje, nepravda i tiranija, pa je stoga nužno uvesti demokratiju i srušiti tiraniju koju su ti isti nasiljem uspostavili, odgajali i brižno čuvali. Ista je stvar i sa sintagmom samoubilački napad. Izmislili su je upravo oni koji su sve vrste nepravde i nasilja počinili nad cijelim svijetom, a posebno nad određenim narodima. Kada je taj teror prešao sve granice i kad se nije mogao više tolerisati niti podnositi, narod je ustao da vrati i odbrani svoja osnovna ljudska prava, pa je reagirao onako kako je znao i umio, jer mu ništa drugo nije preostalo niti su mu dali ikakvo drugo sredstvo da se brani. Onda su savremeni demokrati počeli širiti propagandu kako je to terorizam, divljaštvo, ubijanje nevinih žrtava i šta još sve ne, kako bi na taj način obmanuli svjetsko javno mnijenje i nagnali ga da sažalijeva nasilnike, ubice, silovatelje i uzurpatore nauštrb žrtve.

\section{Objašnjenje i definicija samoubilačkih napada}

Samoubilački napadi se u svijetu nazivaju različitim imenima, sukladno uglu iz kojeg se gledaju, kao i osobi i politici koja ih definira. Neki ih nazivaju samoubilačkim napadima, jer, navodno, u takvim akcijama čovjek vrši suicid - samoubistvo, drugih ih nazivaju šehidskim akcijama, jer se putem njih bori i gine na Allahovom putu, a treći ih zovu odbrambeno-oslobodilačkim akcijama, jer se putem njih čovjek žrtvuje na Allahovu putu i putu oslobođenja svog naroda i domovine.

U viziji islamskog učenja takve akcije bi se mogle definirati kao džihadske akcije koje realizuje pojedinac ili grupa mudžahida sa ciljem nanošenja štete neprijatelju čiji je ishod smrt, a cilj šehadet, najveći stepen vjere. 
Ti napadi su iz domena savremenih ratnih sredstava i metoda koje nisu bile poznate prije i koje mogu imati različite oblike izvođenja i realizacije, poput eksplozivnih pojaseva koje izvršilac opasa oko sebe i aktivira među neprijateljskim vojnicima, ili putem različitih automobila koji se napune eksplozivom, kojim se uđe u neprijateljske kasarne ili sabirne centre i aktivira eksploziv gdje, bez sumnje, mora biti ubijenih. Ovakve i slične akcije se dešavaju danas u Palestini, Iraku, Čečeniji, Afganistanu itd., i to većinom protiv okupatora koji su okupirali te države i njihove stanovnike ponizili i doveli u podanički, robovlasnički položaj. ${ }^{2}$

\section{Oblici samoubilačkih napada}

Samoubilačke akcije kroz ratnu historiju islama imale su raznovrsne oblike i za svaki od njih je važio poseban propis. U nastavku studije ukratko ćemo se osvrnuti na svaki od njih s ciljem da se napravi razlika između njih i savremenih samoubilačkih akcija. Svi ti oblici se načelno mogu podijeliti na dvije vrste ili dva oblika: samoubilačke akcije u kojima se čovjek izlaže smrti od strane njegovih neprijatelja i samoubilačke akcije u kojima čovjek čini samoubistvo.

\section{Prvi oblik ili vrsta}

Pod ovim oblikom se misli na situaciju kada vojnik u borbi sam nasrne na neprijatelja i počne se sam boriti protiv njega. Ovakva akcija se desila u historiji islama na kraju perioda ashaba. Esleme Ebu-Imran, štićenik Kenderija, je rekao: Bili smo u nekom bizantijskom gradu kada su pred nas izveli mnogobrojnu vojsku kojoj se suprotstavila ista ili brojnija vojska. Voda egipatske vojske bio je ashab Allahova Poslanika, s. a. v. s., U'kbe b. Amir. Neki čovjek je navalio na bizantijsku vojsku sve dok nije ušao među njih. Ljudi su za njim vikali govoreći: 'Neka je slava Allahu, svojim rukama se baca u propast.' Ebu-Ejjub el-Ensari je ustao i rekao: 'Ljudi, vi tako tumačite taj ajet, a on je objavljen povodom nas, ensarija. Nakon što je Allah ojačao islam i sljedbenici mu se povećali, tajno smo rekli jedni drugima: Da

\footnotetext{
${ }^{2}$ Vidi: Nevvaf Hajil Tekruri, El-A'melijatul-istišhadije ve suveru ve vesaikul-mukavemetillubnanijje, str. 97., Darul-fikr, Damask, 4. izdanje, 2003. god.
} 
smo se sada fokusirali na svoju imovinu i nadomjestili u našim imanjima on što smo izgubili. Potom je Allah objavio Svome Poslaniku, s. a. v. s., odgovarajući nam: 'I imetak na Allahovom putu žrtvujte, $i$ sami sebe u propast ne dovodite, i dobro činite - Allah, zaista, voli one koji dobra djela čine.' (El-Bekare, 195.) Dakle, propast je bila u posvećivanju našim imecima $i$ njihovom nadoknadivanju i zanemarivanju borbe. Nakon toga, Ebu-Ejjub je učestvovao u svim borbama koje su vođene na Allahovom putu sve dok nije ukupan u bizantijskoj zemlji. ${ }^{3}$

Od Ebu-Derdaa se prenosi da je Poslanik, s. a. v. s., rekao: Trojicu Allah voli, smiješi im se i raduje. Onoga koji, kada se rasplamsa borba, bori se sam u ime Allaha - da bude ubijen ili da ga Allah pomogne i bude mu dovoljan. Tada Allah govori: Pogledajte Mog roba kako se sam strpio za Mene. ${ }^{4}$

O tome svjedoči i slučaj Bera b. Malika u ratu protiv otpadnika sa Jemame. Otpadnici su ušli u jedno utvrđenje i zatvorili vrata. Beraa je rekao: Skupite muslimana, prebacite me do njih u utvrdenje. Ljudi s rekli: Ne čini to, Beraa. Rekao je: Tako mi Allaha, prebacit ćete me do njih. Kada se približio utvrđenju jurnuo je, provalio vrata utvrde i borio se protiv njih sve dok muslimani nisu ušli u nju i osvojili je. ${ }^{5}$

\section{Drugi oblik ili vrsta}

To je oblik kada lice bude izloženo smrti i kada žudi za njom.

Od Ebu-Zerra, r. a., se prenosi da je Poslanik, s. a. v. s., rekao: Trojicu Allah voli: Čovjeka koji navali na neprijatelje pa ih počne ubijati sve dok ga ne ubiju ili donese pobjedu svojim suborcima... ${ }^{6}$

\footnotetext{
3 Bilježi ga Ebu-Davud, 3/1480., Tirmizi, 6/2552 i drugi. Hadis je vjerodostojan sahih.

${ }^{4}$ Bilježi ga Bejheki, El-Esmauves-sifat, 2/849., i Hejsemi u Ez-Zevaidu, 2/525. Hadis je dobar- hasen.

${ }^{5}$ Bilježe ga Taberani, Et-Tarih, 4\&1831., i Ibn-Kesir, El-Bidajetuven-nihaje, 6/325.

${ }^{6}$ Bilježi ga Ahmed, Musned, 18/7811. Hadis je vjerodostojan, vidi: Albani, Sahihuldžamiu', br. 3074 .
} 
Od Ebu-Hurejre, r. a., se prenosi da je Poslanik, s. a. v. s., rekao: Najbolji od ljudi je onaj koji drži povodac svoga konja na Allahovom putu $i$ kad god čuje krike slabih i nemoćnih, požuri i odazove se tražeći tako pogibiju i smrt. ${ }^{7}$

Poslanik, s. a. v. s., je uzimao prisegu od svojih drugova da ne bježe kada se sukobe sa neprijateljem, a možda im je tražio i prisegu na smrt. ${ }^{8}$

\section{Treći oblik ili vrsta}

Ovdje je riječ o situaciji kada lice napadne svog neprijatelja ili svojim životom zaštiti svoje suborce i na taj način da prednost svojoj braći nad sobom. Sam Poslanik, s. a. v. s., je davao prednost svojoj braći nad sobom, pa je prvi išao da se sukobi sa neprijateljem, ne čekajući to od njih. Enes, r. a., je rekao: Poslanik, a. s., je bio najljepši, najplemenitiji i najhrabriji čovjek. Jedne noći su se stanovnici Medine uplašili pa su pobrlili prema glasu kojeg su culi pa ih je sreo. Dakle, Poslanik, s. a. v. s., je pretekao ljude i došao da vidi o čemu se radi. Govorio im je: 'Ne plašite se, ne plašite.' A bio je na golom konju od Ebu-Talhe na kojem nije bilo sedla, a o vratu je imao sablju...

Alija, r. a., je zanoćio u Poslanikovoj postelji kada je učinjena hidžra. Poslanik, a. s., je izišao i sklonio se u pećinu, a idolopoklonici su čuvali Aliju misleći da je Poslanik, a. s. Kada je svanulo, navalili su na njega, pa kada su vidjeli da je Alija, stali su.

Isto tako Ibn-Hadžer navodi da je Ukaše el-Ganimi zaštitio svojim tijelom Poslanika, s. a. v. s., na Uhudu kada su se idolopoklonici okupili da ga ubiju, pa su mu zbog toga odsjekli nos, usne, obrve i uši. ${ }^{10}$

\footnotetext{
7 Bilježe ga Muslim, 5/2467., Nesai, Sunenul-kubra, 12/5513., Ibn-Madže, Sunen, 5/2111. i drugi.

${ }^{8}$ Ibnul-Kajjim, Zadul-mea'd, 3/95.

${ }^{9}$ Muttefekun alejhi

${ }^{10} \mathrm{Ibn}$-Hadžer, El-Isabe, 4/441.
} 
Navedeni i njima slični primjeri gdje ratnik biva izložen ubistvu od strane svog neprijatelja su dozvoljeni zbog dokaza koje smo naveli iz sunneta, ali pod tri uvjeta:

1. da u tom djelu bude interes za muslimana, jer borba nije svrha samoj sebi,

2. da u tom ubistvu, ukoliko ga bude, ne bude opća šteta poput slabljenja morala kod muslimana, te jačanje istog kod nemuslimana, jer je uklanjanje štete preče od pribavljanja koristi, posebno ako se radi o općoj šteti,

3. da takvo djelo bude popraćeno sa potpunom iskrenošću, jer je iskrenost osnova svakog djela i uvjet njegova primanja. Bez iskrenosti djela nemaju nikakvu vrijednost niti sevap, ali ni berićet i uticaj.

Kada se ispune ovi uvjeti, onda se za navedena i slična djela ne može reći da su zabranjena, jer su to lijepa djela koja su otprije radili i ashabi. IbnTejmijje je rekao: Ko uradi ono sto mu je Allah naredio pa ga to dovede do samoubistva, to će se smatrati lijepim kao kad neko sam navali na neprijatelja u čemu je korist za muslimane vjerujuci da će biti ubijen. To je lijep čin. O tome je Allah, dž. š., objavio slijedeći ajet: 'Ima ljudi koji se žrtvuju da bi Allaha umilostivili - a Allah je milostiv robovima Svojim. (El-Bekare, 207.) A i neki ashabi su se bacali na neprijatelja. ${ }^{11}$

\section{Oblici samoubilačkih napada gdje je ratnik izložen samoubistvu}

Ti oblici su:

1. Kada vojnik nanišani neprijatelja, pa pogodi nenamjerno sebe. Takav će imati status šehida, jer nije namjeravao izvršiti samoubistvo. To potvrđuju slijedeće predaje: Ebu-Davud bilježi od nekog ashaba, da je Poslanik, s. a. v. s., rekao: Napali smo Džuhejnijski kvart pa je neko od muslimana tražio nekog čovjeka. Kada ga je našao, zamahao je da ga udari pa je promašio $i$ udario sebe $i$ ubio se. Allahov Poslanik, s. a. v. s., ga je

${ }^{11}$ Ibn-Tejmijje, Medžmu'ul-fetava, 25/279. 
zamotao u njegovu krvavu odjećn i zakopao ga. Ashabi su upitali: 'Allahov Poslaniče, je li on šehid?' 'Jest, i ja mu to svjedočim. ${ }^{12}$

Ibn-Kudame je rekao: Onaj koga pri gadanju neprijatelja ubije njegovo oružje ima status šehida koga je ubio neprijatelj. ${ }^{13}$

2. Kada vojnik bude uvjeren ili skoro uvjeren da će pasti u zarobljeništvo i biti mučen, pa zbog toga izvrši samoubistvo, jer je bio uvjeren da se neće moći strpiti nad tim mučenjima i maltretiranjima. Samoubistvo u ovoj situaciji nije dozvoljeno, jer se ratnik želi na taj način riješiti potencijalnog iskušenja koje bi bio obavezan podnijeti kad se desi, a kako ako se to ne desi?!

Od Džunduba b. Abdullaha se prenosi da je Allahov Poslanik, s. a. v. s., rekao: Bio je prije vas neki čovjek kome je izrastao tumor, pa kad mu je počeo smetati izvadio je strijelu iz tobalka i uklonio ga. Krv mu nije ni potekla, a već je bio mrtav. Poslanik, a. s., je potom rekao: 'Vaš Gospodar mu je zabranio Džennet. ${ }^{14}$

Isto tako se prenosi da je u nekoj bitki jedan čovjek pokazao nadnaravnu hrabrost, ali i pored toga je Poslanik, a. s., za njega rekao da će u Džehennem zbog toga što je nakon toga bio ranjen i nije izdržao bol, nego se ubio svojom sabljom. ${ }^{15}$

Ibn-Tejmijje u tom smislu je odgovorio na pitanje o čovjeku kome pobjegne rob pa se vrati i izvrši samoubistvo: On nije smio izvršiti samoubistvo pa makar mu vlasnik učinio i nepravdu ili ga kaznio ukoliko nije mogao to ukloniti od sebe. Dužnost mu je bila da se strpi i to podnese sve dok mu Allah ne iznade neki izlaz. ${ }^{16}$

\footnotetext{
12 Bilježe ga Ebu-Davud, 3/1499., i Bejheki, Es-Sunenul-kubra, br. hadisa 15078. Hadis je po Albaniju slab - dai'f. Vidi: Albani, Dai'fu Sunen Ebi-Davud, br. hadisa: 546.

13 Ibn-Kudame, El-Mugni, 3/474.

${ }^{14}$ Mutefekun alejhi.

${ }^{15}$ Muttefekun alejhi.

${ }^{16}$ Ibn-Tejmijje, Medžmu'ul-fetava, 31/384.
} 
3. Da bude zarobljen ili je pred zarobljavanjem, a zna bitne tajne, strategiju i namjere muslimana i boji se da ih ne otkrije i na taj način se nanese šteta muslimanima općenito, mudžahidima, posebno s obzirom na mnogobrojna sredstva mučenja i iznude koja posjeduje neprijatelj. Ovakvom vojniku je dozvoljeno izvršiti samoubistvo, jer u samoubistvu je lična šteta, a u otkrivanju strategije i planova muslimana opća, zbog toga što u isto vrijeme nije moguće otkloniti obje štete, pa se stoga sa toleriranjem manje štete uklanja veća, sukladno generalnom pravilu po kojem se podnosi manja šteta radi uklanjanja veće. U tom smislu je i uvaženi šejh Muhammed Ibrahim izdao fetvu na pitanje Alžiraca koje zarobe Francuzi, pa ih opiju radi iznuđivanja podataka o oružju, municiji, zarobljenicima, uglednim oficirima ili vođama - da li im je dozvoljeno u toj situaciji izvršiti samoubistva kako ih ne bi opili i kako im ne bi otkrili tražene podatke. Šejh je rekao da je njihov postupak dozvoljen. ${ }^{17}$

4. Kada se vojnik boji da će, ukoliko ne izvrši samoubistvo nasrćući na neprijatelja, neprijatelj uništiti i iskorijeniti ostale borce, a skoro je uvjeren da ukoliko to uradi da će ih zaustaviti u njihovoj nakani. Samoubistvo u ovakvoj situaciji je dozvoljeno na osnovu istih dokaza koje smo naveli za treći slučaj, pod uvjetom da se to ne može realizirati ni na jedan drugi način. Ovaj stav je sukladan sa pravnim pravilima da je ubistvo nekih bolje od ubistva svih, i kada u kontradiktornost dođu dvije štete - u obzir se uzima veća, a zanemaruje manja. ${ }^{18}$

Ibn-Tejmijje u tom smislu veli: Islamski učenjaci su saglasni da je, ukoliko neprijateljska vojska napravi živi zid od muslimana zarobljenika gdje postoji bojazan da bi mogli na taj način nanijeti štetu muslimanima ukoliko im se ne suprotstavi, dozvoljeno suprotstaviti im se pa makar to dovelo $i$ do ubistva tih muslimana... Muslimani koji su u živom zidu će, ukoliko budu ubijeni,

\footnotetext{
17 Šejh Muhammed Ibrahim Ali Šejh, Fetava ve resail, fetva broj: 1479., 6/207-208. ${ }^{18}$ Ibn-Nudžejm, El-Ešbahu ven-nezair, str. 98., Sujutu, El-Ešbahu ven-nezair, str. 178.
} 
biti šehidi, jer se obligatni džihad ne ostavlja zbog nekoga ko će biti ubijen kao šehid. ${ }^{19}$

5. Da vojnik putem samoubistva namjerava osvetu i nanošenje štete neprijatelju, pa zbog toga izvrši samoubilački napad i na taj način nanese ogromne štete neprijatelju, bilo u imovini ili ljudstvu, gdje će pobiti veliki broj neprijateljskih vojnika i njihovih pomagača. Ovaj oblik je danas najččšci i najviše se dešava u Palestini. On je tema i ove studije i obradit ćemo ga u narednom poglavlju.

\section{Šerijatski status savremenog oblika samoubilačkih napada}

Većina savremenih učenjaka su proučavali ovaj oblik samoubilačkih napada i rekli da je dozvoljen, a neznatna manjina ga zabranjuje. U nastavku studije ćemo se osvrnuti na svako od navedenih mišljenja, kao i njihove dokaze kako bi se objelodanilo preferirano mišljenje po tom pitanju.

\section{Oni koji šehidske akcije zabranjuju i njihovi dokazi}

Neki savremeni učenjaci zabranjuju šehidske napade smatrajući da je to pravo samoubistvo koje vrši onaj koji ih čini, a samoubistvo po islamu je jedan od najvećih grijeha.

Ovo mišljenje zastupa šejh Muhammed Salih el-U'sejmin, Abdul-Aziz Alu-Šejh, šejh Hasan Ejjub i šejh Nasiruddin Albani.

Šejh El-Usejmin je pored ostalog rekao: (...) takvi šehidski napadi se dešavaju u Palestini. Kada pogine jedan Palestinac, na taj način i ubije šest ili sedam židova, židovi će uzeti poslije, zbog toga, šezdeset Palestinaca ili više. Na taj način se nije postigla opća korist za muslimane, a niti je to zaustavilo židove da prestanu vrsiti teror nad Palestincima zbog tih ubistava. Stoga smatramo da ovo što čine neki ljudi putem šehidskih napada, je bespravno samoubistvo koje implicira ulazak u Džehennem i da onaj ko to čini nije šehid. Medutim, ukoliko bi to neko ucinio smatrajući da je to dozvoljeno, nadamo se da će biti sačuvan od grijeha. Ali je nemoguce da

${ }^{19}$ Ibn-Tejmijje, Medžmu'ul-fetava, 28/548. 
bude šehid, jer nije slijedio puteve šehadeta. A ko bude idžtihadio pa pogriješio, imat će nagradu. ${ }^{20}$

Alu-Šejh je, kada je bio upitan o samoubilačkim napadima koji se vrše u Palestini, odgovorio: Za tako nešto nema presedana u Šerijatu. Bojim se da to ne bude suicid... ${ }^{21}$

Šejh Albani ne zabranjuje samoubilačke napade zbog načina na koji se oni izvode, nego zbog nepostojanja vladara - halife koji za to treba da izda naređenje. Dakle, ovdje on zasniva svoje mišljenje na principu da nema džihada bez postojanja vladara - halife. ${ }^{22}$

\section{Dokazi onih koji zabranjuju šehidske napade}

Zagovornici ovog mišljenja svoj stav izvode iz dokaza iz Kur'ana, sunneta i logike.

\section{Iz Kur'ana:}

1. Uzvišeni Allah je rekao: Sami sebe u propast ne dovodite, i dobro činiteAllah, zaista, voli one koji dobra djela čine (El-Bekare, 195.). Onaj koji učini takav napad, sam sebe je bacio u propast čiji uzroci su nakon toga kategorični, a ne umišljeni.

\section{Iz sunneta:}

2. Od Ebu-Hurejre, r. a., se prenosi da je Allahov Poslanik, s. a. v. s., rekao: Ko izvrši samoubistvo sa nekim željezom, s njim će vječno u Džehennemu probadati svoj stomak. Ko se otruje sa nekim otrovom, trovat će se vječno $u$ džehennemskoj vatri. Ko se baci sa neke litice i ubije se, $u$ džehennemskoj vatri će se tako vječno bacati. ${ }^{23}$

\footnotetext{
${ }^{20}$ El-U'sejmin, Šerhu Rijadis-salihin, 1/99., Darul-iman, El-Mensure, Misr.

21 Nevvaf Hajil Tekruri, El-A'melijatul-istišhadije ve suveru ve vesaikul-mukavemetillubnanijje, str.179.

${ }^{22}$ Albani, Silsile: El-Hudaven-nur, broj audikasete: 134.

${ }^{23}$ Muttefekun alejhi.
} 
3. Prenosi se vjerodostojnom predajom da je u nekoj bitki jedan čovjek pokazao nadnaravnu hrabrost, ali i pored toga Poslanik, a. s., je za njega rekao da će u Džehennem zbog toga što je bio ranjen i nakon izvjesnog vremena nije izdržao bol nego se ubio svojom sabljom. ${ }^{24}$

\section{Iz logike:}

Takve akcije donose više štete nego koristi, jer ako neko ubije sebe i ubije još deset, sto ili dvjesta, islam od toga neće imati nikakve koristi i ljudi ga neće priznati kao heroja, nego je moguće da to učini neprijatelja još opasnijim, žešćim i nemilosrdnijim prema muslimanima. Takav je slučaj danas u Palestini. Kad Palestinac izvrši šehidski napad, on ubije sebe i još nekoliko židova, koji nakon toga pozatvaraju na stotine Palestinaca, tako da od toga muslimani nemaju nikakve koristi, a niti je imaju oni koji pripremaju i izvode takve napade. ${ }^{25}$

\section{Mišljenje onih koji dozvoljavaju samoubilačke napade smatrajući ih šehidskim napadima}

Protagonisti koji zastupaju ovo mišljenju su većina savremenih islamskih pravnika. Među njima su: Jusuf el-Karadavi, Fethi Durejni, Nei'm Jasin, Sulejman Eškar, Ali Savva, Osman Šubejr, Mahmud Sartavi, Ahmed Nevfel, Vehbe Zuhajli, Ramadan Buti, Muhammed Hajr Hejkel, Selman 'Avde, A'džil Džasim en-Nešvi, Sudanska akademija islamskog prava, Liga palestinskih i iračkih učenjaka, kao i mnogi drugi učenjaci i univerzitetski profesori u islamskom svijetu.

Sulejman Meni' je o samoubilačkim napadima rekao: Bez sumnje samoubilački napadi na Allahovom putu protiv Allahovih neprijatelja, neprijatelja Allahova Poslanika i neprijatelja muslimana su plemenito djelo putem kojeg se musliman približava Allahu. To je bez sumnje najbolji oblik džihada na Allahovom putu. Ko pogine u takvim napadima je, ako Bog da, šehid. Mi u historiji islama, za vrijeme Poslanika, pravednih halifa $i$ onih

\footnotetext{
${ }^{24}$ Muttefekun aljehi.

${ }^{25}$ El-U'sejmin, Šerhu Rijadis-salihin, 1/99.
} 
koji su došli poslije njih, imamo mnogobrojne oblike džihada na Allahovom putu. Onaj koji izvodi takve akcije treba da ima lijep nijet i da mu namjera bude samo džihad na Allahovom putu, da se ne baca svojim rukama $u$ propast $u$ akcijama gdje preovladava uvjerenje da se nece nista postici sa njihovim izvršenjem $i$ da takve akcije ne izvodi protiv islamskih lidera na osnovu posebnog tumačenja, jer poziv i savjet vladarima ne znači i ustajanje protiv njih, nego da se posavjetuju sa mudrošcu, lijepim savjetom i uzoritim odnosom pri savjetovanju.

Šejh Selman A'vde je, nakon što je naveo neke dokaze iz historijskih dogadaja, rekao: Iz svega se preferira, a Allah najbolje zna, da je dozvoljeno izvrsiti takve akcije pod uvjetima da budu izvršene na način kako su to pravnici naveli.

Sudanska akademija islamskog prava je 8. 5. 2001. godine izdala slijedeću fetvu:

U osnovi, sve što mudžahid čini s namjerom nanošenja štete neprijatelju i njegovog uznemiravanja je lijepo i poželjno. Sve što zastrašuje Allahove neprijatelje i neprijatelje Njegova Poslanika i muslimana je poželjno. Ko namjerava oslabiti neprijatelja, nanijeti mu štetu, uznemiriti ga i zastrašiti tražeći time Allahovo zadovoljstvo, pa sa tim nijetom napadne mnogobrojnijeg neprijatelja ili nasrne na njega, pa makar i bio uvjeren da će biti ubijen ili mrtav, sve se to smatra džihadom i šehidskim legalnim djelima koja potvrđuju dokazi i praksa ashaba poslije njih. Na taj način se ostvaruju ogromni interesi, kako za njega, tako i za ummet, a neki od tih interesa su:

1. izvršilac na taj način traži šehadet,

2. ohrabruje muslimane $\mathrm{i}$ motiviše ih da ustanu protiv neprijatelja okupatora,

3. nanosi ogromnu štetu neprijatelju, 
4. slabi moral kod neprijatelja, jer kad pojedinac može sve to uraditi, šta bi sve onda mogli uraditi kao kolektiv ${ }^{26}$

Palestinska liga učenjaka povodom šehidskih napada izdala je slijedeći proglas:

Ove šehidske akcije su džihad na Allahovom putu, jer se putem njih nanosi šteta židovskom neprijatelju poput ubijanja, straha, zastrasivanja, uznemiravanja, podrivanja temelja njihove države, što ih nagoni da razmišljaju o odlasku iz Palestine. Ti napadi, takoder, smanjuju broj židovskih useljenika u Palestinu, nanose im ogromne materijalne štete $i$ slabe njihovu moć i moral. Oni su, takoder, našem narodu donijeli veliku korist, podigli moral i ohrabrili našu omladinu na džihad $i$ šehadet. Prethodni $i$ potonji učenjaci su donijeli fetvu da su ovakvi napadi dozvoljeni $i$ da su propisani Kur'anom, sunnetom i konsenzusom.

Doktor Karadavi je za šehidske napade koje izvršava muslimanska omladina braneći svoju domovinu, vjeru i čast rekao da su najveličanstveniji oblik džihada. Oni su legalan način zastrašivanja neprijatelja na kojeg je ukazao i Kur'an: I protiv njih pripremite koliko god možete snage i konja za boj, da biste time zaplašili Allahove $i$ vaše neprijatelje, i druge osim njih - vi ih ne poznajete, Allah ih zna (El-Enfal, 60.). Doktor Karadavi smatra da je naziv tih akcija pogrešan i obmanjujući, jer to ni u kom slučaju nisu samoubilački napadi, nego hrabre džihadske i dobrovoljačke akcije, a ne suicidne. Oni koji poginu u njima smatraju se šehidima na Allahovom putu sve dok im je nijet čist i sve dok su prisiljeni da na takav način zastrašuju Allahove neprijatelje. Svoj stav je potkrijepio jasnim tekstovima Kur'ana i sunneta i pripisao ga osmerici imama islamskog prava a to su: El-Džessas - hanefijski pravnik, Kurtubi - malikijski, Razi - šafijski, Ibn-Kesir, Taberi, Ibn-Tejmijje i Ševkani. ${ }^{27}$

\footnotetext{
26 Medžmeu'l-fikhil-islami, Sudan. Vidi: Hajil Tekruri, El-A'melijatul-istišhadije ve suveru ve vesaikul-mukavemetil-lubnanijje, str. 152-153.

27 Šeri'jetul-a'melijat el-istišhadijje fil-eradil-muhtelle, www.qaradawi.net (subota, 03.11.2001.god.)
} 


\section{Dokazi onih koji dozvoljavaju šehidske napade}

Svoje mišljenje temelje na dokazima iz Kur'ana, sunneta, konsenzusa i racionalnim dokazima.

\section{Iz Kur'ana:}

1. Uzvišeni Allah je rekao: Ima ljudi koji se žrtvuju da bi Allaha umilostivili - a Allah je milostiv robovima Svojim (El-Bekare, 207.). Ashabi su smatrali da se ovaj ajet odnosi na onoga koji navali na mnogobrojnog neprijatelja, pa makar bio i sam. To se prenosi od Omera b. el-Hattaba i Ebu-Hurejre, r. a., kako se navodi u tefsirima. ${ }^{28}$

Od Mugire se prenosi da je rekao: Omer je poslao vojsku koja je opsjedala jednu tvrdavu. Jedan od vojnika je sam istupio naprijed $i$ borio se sve dok nije poginuo. Ljudi su o njemu počeli pričati govoreći: 'Svojom rukom se baci u propast?!' To je doprlo da Omera, r. a., pa je rekao: 'Slagali su. Zar Allah nije rekao: Ima ljudi koji se žrtvuju da bi Allaha umilostivili - a Allah je milostiv robovima Svojim.' 29

Od Muhammeda se prenosi da je rekao: Hišam b. A'mir je napao stroj vojnika $i$ probio ga. Rekli su: 'Bacio se svojim rukama u propast.' EbuHurejre je rekao na to: 'Ne, nego je praktično primijenio ovaj ajet: 'Ima ljudi koji se žrtvuju da bi Allaha umilostivili - a Allah je milostiv robovima Svojim.' 30

2. Uzvišeni je rekao: Allah je od vjernika kupio živote njihove i imetke njihove u zamjenu za Džennet koji će im dati-oni će se na Allahovu putu boriti, pa ubijati i ginuti. On im je to zbilja obećao u Tevratu, i Indžilu, $i$ Kur'anu - a ko od Allaha dosljednije ispunjava obećanje Svoje? Zato se radujte pogodbi svojoj koju ste s Njim ugovorili, $i$ to je veliki uspjeh (EtTevba, 111.). O vjernici, hoćete li da vam ukažem na trgovinu, ona će vas spasiti patnje nesnosne: u Allaha i Poslanika Njegova vjerujte $i$ imecima

\footnotetext{
${ }^{28}$ Vidi: Kurtubi, Tefsir, 2/729., i Taberi, Tefsir, 2/348.

${ }^{29}$ Bilježe ga: Ibn Ebi-Šejbe u El-Musannefu, 10/4989., i Bejheki u Es-Sunenul-Kubra, $9 / 46$.

${ }^{30}$ Bilježi ga Bejheki, Šua'bul-imani, 3/160.
} 
svojim i životima svojim na Allahovu putu se borite - to vam je, da znate, bolje. On će vam grijehe vaše oprostiti i u džennetske bašče vas, kroz koje će rijeke teci, uvesti, $i$ u divne dvorove u edenskim vrtovima; to ce biti uspjeh veliki, a dat će vam i drugu blagodat koju jedva čekate: Allahovu pomoć $i$ skoru pobjedu! Zato obraduj radosnom viješću vjernike! (Es-Saff, 10 - 13.)

Ako je vjernik prodao svoj život Uzvišenom Allahu za Džennet i ako je Uzvišeni Allah kupio od vjernika njegov život po toj cijeni, dakle vjernikov džihad na Allahovom putu je trgovinska transakcija gdje se razmjenjuju dvije robe: život, kojeg vjernik žrtvuje i Džennet kao njegova cijena, u tom slučaju samoubilačke akcije su u biti samo ova trampa.

3. Uzvišeni je rekao: I protiv njih pripremite koliko god možete snage $i$ konja za boj, da biste time zaplašili Allahove i vaše neprijatelje, i druge osim njih - vi ih ne poznajete, Allah ih zna (El-Enfal, 60.). Šehidske akcije su jedna vrsta snage koja ih zastrašuje. To je jedina snaga koju mogu pripremiti mudžahidi u Palestini, kao i u ostalim muslimanskim zemljama koje su neprijatelji oteli i uzurpirali. Prema tome, ukoliko neprijatelj zastrašuje muslimane sa sofisticiranim oružjem i oružjem za masovno uništenje koje posjeduje i na taj način ih je pretekao u naoružanju i tehnologiji, onda mudžahid musliman ima pravo zastrašivati Allahove neprijatelje i neprijatelje vjernika oružjem u kojem on ima prednost, a to je traženje smrti i ljubav prema njoj kao što oni žude za ovozemaljskim životom i vole ga.

\section{Iz hadisa:}

1. Kazivanje o dječaku i sihirbazu ${ }^{31}$ je poznato kazivanje gdje se kaže da im je dječak rekao kako će ga ubiti, pa su tako postupili i ubili ga. On je umro kao šehid na Allahovom putu. Ovakva vrsta džihada donosi ogromnu koristi i veliki interes muslimanima, jer su nakon toga stanovnici tih krajeva primili islam i rekli: Mi vjerujemo u dječakova Gospodara. Dakle, taj mladić, mudžahid, odvažio se i bio uzrok da mu se oduzme život radi općeg interesa muslimana. Podučio ih je kako će ga

\footnotetext{
${ }^{31}$ Hadis je sahih. Bilježe ga: Muslim, Sahih, 8/3731., Ahmed, Musned, 20/9989., IbnEbi-Šejbe, Musannef, 1/201., Ibn-Hibban, Sahih, 2/942., Taberani, El-Kebir, 9/4231.
} 
ubiti, jer ga nisu mogli ubiti osim samo na način kako ih je podučio, pa je stoga on uzrokovao svoju smrt. Međutim, to se u džihadu oprašta. Ista je stvar i sa mudžahidima u šehidskim - samoubilačkim akcijama. On je uzrok vlastite smrti radi općih interesa muslimana.

2. Postupak Beraa b. Malika u bitki na Jemami kada se sam bacio na neprijatelja i borio se sve dok nije otvorio vrata i niko ga zbog toga nije osudio od ashaba. ${ }^{32}$

3. Selem b. el-Ekva' i Ebu-Katade su pojedinačno napali Ujejne b. Hisna i one koji su bili sa njim. To je Poslanik, s. a. v. s., pohvalio i rekao: Najbolji od naših ljudi je Seleme. ${ }^{33}$ Ibn-Nahhas je rekao: $U$ ovom potvrdenom $i$ vjerodostojnom hadisu je najbolji dokaz da je dozvoljeno jednom da napadne mnogobrojnu neprijateljsku skupinu i pored toga što je pretežno ubijeden da će biti ubijen ukoliko bude iskren u traženju šehadeta kao što je uradio i Selem b. el-Ekva'. Ni Poslanik, s. a. v. s., a niti ashabi, r. a., ga nisu ukorili zbog toga. U hadisu je čak i dokaz koji ukazuje na poželjnost $i$ pohvalnost takvog djela, jer je Poslanik, s. a. v. s., kako smo naprijed $i$ vidjeli, pohvalio djelo koje su učinila dvojica ashaba i pored toga što su njih dvojica sami napali neprijatelja ne čekajući da im se pridruže muslimani. ${ }^{34}$

4. Djelo koje je počinio Hišam b. A'mir el-Ensari kada je sam upao među dva reda neprijateljskih vojnika i nasrnuo na mnogobrojnog neprijatelja. Neki su mu to zamjerili rekavši da se svojim rukama bacio u propast, pa su im na to odgovorili Omer b. el-Hattab i Ebu-Hurejre, r. a., i citirali slijedeći ajet: Ima ljudi koji se žrtvuju da bi Allaha umilostivili - a Allah je milostiv robovima Svojim (El-Bekare, 207.).

\section{Konsenzus:}

Ibn-Nahhas u djelu Mešariu'l-ešvak prenosi konsenzus od Muhelleba: Učenjaci su saglasni konsenzusom da je dozvoljeno upustiti se u neizvjesne

\footnotetext{
32 Bilježe ga: Taberi, Et-Tarih, 4/1931., Ibn-Kesir, El-Bidajeven-nihaje, 6/325.

33 Hadis sahih bilježi ga Muslim i ostali.

${ }^{34}$ Mešariu'l-ešvak, $1 / 540$.
} 
situacije u džihadu. ${ }^{35}$ Gazali je rekao: Nema dileme oko toga da je jednom muslimanu dozvoljeno napasti kolonu nevjernika $i$ boriti se protiv njih $i$ pored toga što zna da će biti ubijen. ${ }^{36}$

\section{Analogija na živi zid}

Ako bi nevjernička vojska uzela muslimane kao živi zid kako bi im na taj način spriječila daljnje napredovanje ili porazila ih, bilo bi im dozvoljeno napasti neprijatelja i pored tog živog zida. Ibn-Tejmijje je rekao: Islamski učenjaci su saglasni da je dozvoljeno ukoliko neprijateljska vojska uzme živi zid od muslimana zarobljenika gdje postoji bojazan da bi mogli nanijeti stetu muslimanima ukoliko im se ne suprotstavi, dozvoljeno je suprotstaviti im se pa makar to dovelo do ubistva tih muslimana... Oni će, ukoliko u tom slučaju budu ubijeni, biti šehidi, pa se stoga ne ostavlja obligatni džihad zbog nekoga ko će biti ubijen kao šehid." ${ }^{\text {“37 }}$

Ibn-Kasim u djelu Hašijetu-Ruved je rekao: U Insafu je rečeno da kada se nevjernici zaštite sa muslimanima da ih nije dozvoljeno gadati ukoliko nema bojazni za muslimane. U suprotnom je dozvoljeno pod uvjetom da se nanijete nevjernici i oko ovoga nema nikakve dileme. ${ }^{38}$

Prema tome, ako je u navedenom slučaju dozvoljeno ubiti muslimana od strane drugog muslimana zbog neprijatelja, onda je samoubistvo mudžahida zbog nanošenja štete neprijatelju manji prekršaj. Dakle, ako je djelo koje je na većem stepenu prekršaja dozvoljeno učiniti, onda je preče da bude dozvoljeno ono koje je na manjem stepenu prekršaja pod uvjetom da u oba slučaja nijet bude nanošenje štete neprijatelju sukladno hadisu: Djela se vrednuju po namjerama.

U ovom citatu se također nalazi i odgovor onima koji smatraju da onaj koji sam napadne mnogobrojnijeg neprijatelja da biva ubijen od strane

\footnotetext{
${ }^{35}$ Mešariu'l-ešvak, 1/588.

36 Ibid.

${ }^{37}$ Ibn-Tejmijje, Medžmu'ul-fetava, 28/537, 546., 20/52.

${ }^{38}$ Hašijetu-Ruved, 4/271.
} 
neprijatelja i njihova oružja. Ovdje je, međutim, drugačija situacija, jer muslimani bivaju ubijeni od strane drugih muslimana, ali se ipak to ne smatra ubistvom za kojeg su propisane ovosvjetske i onosvjetske kazne.

\section{Opći interes}

Putem džihada se štiti i čuva vjera kao i život, potomstvo, čast i imovina od okupacije i premoći nevjernika. Kada neprijatelj preuzme vlast i pobijedi, nastaju slijedeće posljedice:

a) Zabrana vjernicima da upražnjavaju vjerske obrede i vršenje raznih vrsta pritisaka na njih,

b) dominacija i primjena zakona i pravila koja su oprečna islamu,

c) rezerviranosti stanovnišstva prema vjeri nakon što vidi poniženost $\mathrm{i}$ ugroženost vjernika.

Ista ili slična se šteta postiže i kod uništenja života, potomstva, časti i imovine.

Ibn-Tejmijje je rekao: Muslim u svom Sabihu bilježi od Poslanika, s. a. v. s., kazivanje o vlasnicima rovova - ashabul-uhdud mectu kojima je bio $i$ dječak kojemu je bilo naredeno da se ubije zbog interesa vjere. Na osnovu toga četverica imama dozvoljavaju muslimanu da sam nasme na neprijatelja zbog trijumfa interesa vjere $i$ pored toga što je skoro ubijecten da će biti ubijen ukoliko u tom napadu postoji interes za muslimane. Kada covjek uradi nešto zbog čega je uvjeren da će biti ubijen radi općeg interesa islama, $i$ pored toga što je samoubistvo veći grijeh od ubistva drugog, ali radi interesa vjere koji se ne može postići osim na taj način, a niti se šteta koja je narušava može ukloniti na neki drugi način, samoubistvo je u tom slučaju preče. ${ }^{39}$

\section{Diskusija i preferiranje}

Analizirajući dokaze na osnovu kojih su donesena navedena mišljenja, zapazili smo slijedeće:

${ }^{39}$ Ibn-Tejmijje, Medžmu'ul-fetava, 28/540. 
1. Dokazi na kojima protagonisti koji zabranjuju samoubilačke napade temelje svoje mišljenje ne ukazuju na to da su oni zabranjeni. Kontekst ajeta kojeg navode kao svoj glavni dokaz podstiče vjernike da troše na Allahovom putu i da se ne izlažu propasti, zanemarujući tu obavezu od koje zavisi njihova snaga, moć, ponos i sreća na ovom svijetu i spas na drugom. Ovakvo poimanje ajeta potvrđuju i najpoznatiji komentatori Kur'ana poput Ibn-Abbasa, Mudžahida, Ikrime, Seida b. Džubejra, Atae, Dahhaka, Hasana, Katade, Suddija, Mukatila, Ibn-Hajjana, Huzejfe i drugih. ${ }^{40}$

Ovo objašnjenje potvrđuje i predaja koju bilježi Buharija od Huzejfe, r. a.: Sami sebe u propast ne dovodite, $i$ dobro činite - Allah, zaista, voli one koji dobra djela čine (El-Bekare, 195.). ${ }^{41}$ Oni koji ga ne tumače u značenju dobročinstva, a to je neznatan broj mufessira, tvrde da ukazuje na čovjeka koji pogriješi i ne pokaje se ili čovjeka koji počini grijeh i kaže da mu se neće oprostiti, pa nastavi s griješenjem i upropasti sam sebe. Od prethodnika se prenose predaje koje negiraju tumačenje ajeta na način kako su ga razumjeli oni koji zabranjuju samoubilačke akcije. Tako se prenosi od Ebu-Ejjuba el-Ensarije u kazivanju o Istanbulu da je osudio one koji su razumjeli ajet na tako pogrešan način rekavši: Ljudi, vi tumačite ovaj ajet na takav način, a propast spomenuta u ajetu se odnosi na bavljenje imovinom i njenom nadoknadom naustrb borbe na Allahovom putu.

A što se tiče njihovih dokaza iz hadisa, u njima se zabranjuje suicid, a ne samoubilački napadi, jer ako konsultujemo rječnike i pravna djela i pogledamo značenje riječi el-muntehir u jeziku i Šerijatu, zapazit ćemo da nema sličnosti između onoga koji izvrši samoubistvo zbog imetka ili bojazni od siromaštva i bijede na ovome svijetu i dobrovoljca koji žrtvuje svoju dušu i uzrokuje svoje ubistvo zbog vjere i zaštite svoje čast, porodice, potomstva i svog naroda.

\footnotetext{
${ }^{40}$ Ibn-Kesir, Tefsirul-Kur'anil-a'zim, 1/217.

${ }^{41}$ Buhari, Sahih, 7/3281.
} 
Stoga je izjednačavanje suicida, koji je po Kur'anu, sunnetu i konsenzusu zabranjen, sa šehidskim akcijama neprihvatljivo i nepravedno, jer je nemoguće izjednačiti čovjeka koji ubije sebe na sotonskom putu i onoga koji žrtvuje svoj život na putu Onoga koji je najmilostiviji. Samoubica izvršava suicid nad sobom zbog straha, nestrpljenja, manjka vjerovanja $u$ Božije određenje itd., a dobrovoljac ubija sebe ili uzrokuje svoju smrt da bi ojačao vjeru, uništio neprijatelje, oslabio njihovu moć, poljuljao njihovu vlast i uklonio njihovu laž i obmanu kojom obmanjuju cijeli savremeni svijet pomoću dimnih zavjesa svoje propagande i laži, ne dozvoljavajući mu da se istinski upozna sa Božijom uputom i putem koji ih neminovno vodi ka sreći na ovom i spasu na budućem svijetu.

Analogija onoga koji pogine u šehidskim akcijama sa onim koji izvrši suicid je inkompatibilna analogija. Postoje mnogobrojne razlike koje sprječavaju da se te dvije situacije poistovjete. Da li se samoubica koji ubije sam sebe iz nestrpljenja, ili nezadovoljstva sudbinom, ili revolta prema onome što je određeno, ili očaja i beznađa - može izjednačiti sa mudžahidom koji u šehidskim akcijama žrtvuje svoj život tražeći Božije zadovoljstvo, Džennet i trijumf vjere?! Uzvišeni je rekao: Zar ćemo muslimane sa nevjernicima izjednačiti?! Šta vam je, kako rasudujete? (ElKalem, 35-36.) Misle li oni koji ćine zla djela da ćemo s njima postupiti jednako kao sa onima koji vjeruju i dobra djela čine, da će im život i smrt biti isti? Kako loše rasuduju! (El-Džasije, 21.)

2. Moguće je replicirati dokazima onih koji šehidske akcije ne dozvoljavaju i reći da se oni ne odnose na oblik akcije oko koje se vode nesuglasice, nego samo na onu situaciju kada borac napadne neprijatelja, pa ga ubiju, ali ne i na onu kada on sam sebe ubije. Međutim, na ovu repliku je moguće reći da ne postoji suštinska razlika između navedenih situacija koje bi implicirale distinkciju propisa, jer kakve ima razlike u Šerijatu između šehidskih akcija i između napada na neprijatelja gdje prevladava ubjeđenje da će napadač biti ubijen?! Hadisi koji govore o odlikama takvog napada i nagradi koja čeka njegova izvršioca, i pored toga što će biti ubijen i što će mu se krv proliti, dostigli su stepen tevatura. 
Ako neko primijeti da onaj koji sam navali na neprijatelja pa ga ubije i dobrovoljca koji ubije sam sebe imaju isti status, jer je poznata situacija $u$ Šerijatu da uzročnik samoubistva i saučesnik imaju status direktnog ubice. Ovo je mišljenje većine pravnika: Malika, Šafije i Ahmeda. Svi oni smatraju da se odmazda mora sprovesti nad uzročnikom ubistva kojeg je namjerno uzrokovao, poput onoga koji namjerno iskopa bunar da bi neko pao u njega, pa upadne i pogine. Ima i pravnika koji imaju suprotno mišljenje navedenom, koji smatraju da je u takvom slučaju neophodno platiti krvarine, a ne izvršiti odmazdu. Međutim, i oni su stava da je to zabranjeno što je ovdje i najvažnije. Ipak je mišljenje većine pravnika jače po smislu i eksplicitnije po dokazima. Po njemu je i Omer, r. a., izdao fetvu. Dokazi na kojima se temelji su mnogobrojni i moguće ih je konsultovati u pravnim djelima. Prema tome, ako uzročnik samoubistva ima isti status neposrednog njegova izvršioca, po pitanju njegove zabrane i kompenzacije - odmazde i krvarine, pod uvjetom da je to namjeravao, zbog čega onda praviti razliku između uzročnika i neposrednog samoubice kod dozvole šehidskih akcija i njihove šerijatske legalnosti, ako je njihov izvršitelj pri njihovu izvršenju namjeravao postići zadovoljstvo Uzvišenog Allaha?!

\section{Odabrano mišljenje}

Nakon kritičkog osvrta na dokaze navedenih mišljenja, smatramo da su šehidske akcije dozvoljene i legalne po Šerijatu i to zbog slijedećih razloga:

Prvo: Zbog jačine dokaza na kojima temelje svoje mišljenje protagonisti koji dozvoljavaju te akcije, njihove kompatibilnosti sa šerijatskim intencijama i prirodi džihada u islamu, za razliku od slabosti dokaza na kojima počiva suprotno mišljenje i njihove nepostojanosti pred kritikama.

Drugo: Džihad u osnovi počiva na žrtvovanju života od strane muslimana radi postizanja šerijatskih većih interesa. Dakle, džihad je u osnovi žrtvovanje života i imetka na Allahovom putu zbog dva cilja: onosvjetskog, koji se ogleda u jačanju vjere i njene praktične primjene na ovom svijetu i onosvjetskog, koji se reflektuje kroz stjecanje šehadeta i 
nagrade koja je obećana šehidima. Stoga je Kur'an džihad opisao kao trgovinu i kupoprodaju gdje je objasnio oba cilja u slijedećim ajetima:

Allah je od vjernika kupio živote njihove $i$ imetke njihove u zamjenu za Džennet koji će im dati - oni će se na Allahovu putu boriti, pa ubijati $i$ ginuti. On im je to zbilja obećao u Tevratu, i Indžilu, i Kur'anu - a ko od Allaha dosljednije ispunjava obećanje Svoje? Zato se radujte pogodbi svojoj koju ste s Njim ugovorili, $i$ to je veliki uspjeh (Et-Tevbe, 111.).

O vjernici, hoćete li da vam ukažem na trgovinu, ona će vas spasiti patnje nesnosne: u Allaha i Poslanika Njegova vjerujte $i$ imecima svojim i životima svojim na Allahovu putu se borite - to vam je, da znate, bolje - On će vam grijehe vaše oprostiti i u džennetske bašče vas, kroz koje će rijeke teći, uvesti, $i$ $u$ divne dvorove u edenskim vrtovima; to će biti uspjeh veliki, a dat će vam $i$ drugu blagodat koju jedva čekate: Allahovu pomoć i skoru pobjedu! Zato obraduj radosnom viješću vjernike! (Es-Saff, 10-13.) Dakle, temelj na kojem je postavljen džihad $\mathrm{u}$ islamu je isti temelj na kom se zasnivaju i šehidske akcije.

Treće: Ne postoji razlika između toga da mudžahid sam navali na neprijatelja znajući da će biti ubijen, što je dozvoljeno kako smo to u studiji i objasnili, i između toga da ubije sam sebe kako bi nanio štetu neprijatelju, jer motiv i nakana u oba slučaja je isti kao i posljedice. Ostalo je, dakle, samo sredstvo. Nakon podrobnog i objektivnog razmišljanja, može se zaključiti i reći da je to samo jedno sredstvo ubistvo radi nanošenje štete neprijatelju ili nanošenje štete neprijatelju putem ubistva. Razlika je samo u načinu primjene tog sredstva, jer se $\mathrm{u}$ prvom slučaju ubija posredstvom neprijatelja, a u drugom neposredno. U oba slučaju ishod je isti - samoubistvo putem kojega se nanosi šteta i propast neprijatelju radi realizacije općih interesa muslimana.

Četvrto: U pitanjima u kojima postoji balansiranje između dozvoljene sigurnosti i između žrtvovanja čiji je ishod smrt - pogibija, daje se prednost pogibiji nad mogućom i dozvoljenom sigurnosti. Postoje jasni dokazi u kojima se očito preferira strpljenje i smrt nad mogućom i dozvoljenom sigurnosti, od kojih su: 
a) Kod prisile na otpadništvo. Onaj ko bude prisiljen na otpadništvo i pored toga što ima pravo izreći ga, kako stoji u riječima Uzvišenog, ipak se bolje strpiti i ne učiniti ga: Onoga koji zaniječe Allaha, nakon što je u Njega vjerovao - osim ako bude na to primoran, a srce mu ostane čvrsto u vjeri - čeka Allahova kazna. One kojima se nevjerstvo bude mililo stići će srdžba Allahova $i$ njih čeka patnja velika (En-Nahl, 106.). Učenjaci su saglasni da je bolje i sevapnije strpiti se. Ibn-Bettal je rekao: Po konsenzusu učenjaka veću nagradu kod Allaha ima onaj koji izabere kod prisile na nevjerstvo ubistvo nad olakšicom. ${ }^{42}$

b) Kada muslimana u borbi bude duplo manje od nevjernika, dozvoljeno im je tada napustiti bojno polje na osnovu riječi Uzvišenog: Ako vas bude stotina izdržljivih, pobijediće dvije stotine (El-Enfal, 66.). Kao i IbnAbbasovih riječi: Ko pobjegne od dvojice uistinu je pobjegao, a ko pobjegne od trojice ne smatra se da je pobjegao. ${ }^{43}$

Ali i pored toga, u takvim situacijama je poželjno da se musliman strpi i ne bježi, pa makar pretežito bio i uvjeren da će biti ubijen radi postizanja stepena šehida hrabro se boreći i nadajući se Allahovoj nagradi. Takav vojnik je bolji od onog koji se povuče. ${ }^{44}$ Međutim, navedeni propis se ne može primijeniti na situaciju u kojoj opći interes islama nalaže da se vojska ili vojnik povuče $s$ jednog položaja na drugi, ili da se priključi drugoj jedinici ili odredu.

c) Učenjaci navode da je u određenim situacijama muslimanu dozvoljeno dati prednost drugom nad sobom pa makar to za posljedice imalo i njegovu smrt. U tom smislu Ibnul-Kajjim je rekao: Kada odredenu grupu zadesi velika žed $i$ na vidiku vide smrt zbog nje, a neko od njih bude imao vode, on ima pravo da je da drugom $i$ da se preda smrti. Takav postupak je dozvoljen i neće se za takvog reći da je ubio sam sebe, a niti da je uradio

\footnotetext{
42 Kurtubi, Tefsir, 6/3804-3805.

43 Bilježe ga Sei'd b. Mensur, Sunen, 2/681., Ibn-Ebi-Šejbe, El-Musannef, 19/9478., Taberani, El-Kebir, 13/6013., Bejheki, Es-Suneneul-kubra, 24/11955. Hadis je sahih. Vidi: El-Albani, El-Irva', br. hadisa: 1206.

${ }^{44}$ Ibn-Kudame, El-Mugni, 13/189.
} 
zabranjeno, nego će se smatrati vrhuncem plemenitosti i altruizma, kao sto je Uzviseni rekao: 'I daju prednost drugima iako su i sami potrebni.' Takva situacija se desila nekim ashabima pri osvojenju Šama i to im se ubrojalo u njihove lijepe postupke i odlike. ${ }^{45}$

d) Neki pravnici navode da je vojskovođi dozvoljeno da podstiče vojnike na borbu, tj. da se i oni koji to žele izlože ubistvu i šehadetu, a čiji bi takvi postupci neminovno uticali na vojsku u smislu podizanja njezinog borbenog morala. ${ }^{46}$ Prema tome, ako je ovakvo pravilo i zakon u Šerijatu i ako šehidske akcije počivaju na takvim zakonima i pravilima, onda je logično postaviti pitanje: zbog čega onda da budu zabranjene?!

Peto: Ako bi neko htio da izvrši suicid zbog toga što je izgubio nadu u Allahovu milost $\mathrm{i}$ to odluči, ali na jedan posredan način da namjerno izazove nekoga da ga ubije, postavlja se pitanje kakav je njegov status? Ako kažemo da nije samoubica, u tom slučaju bismo otvorili širom vrata intrigama i putevima ka neredu i anarhiji. A ukoliko kažemo da je samoubica, jer nema razlike između posrednog i neposrednog ubistva, onda bi bila dužnost reći to isto i kada su u pitanju šehidske akcije.

Šesto: Uzvišeni Alah nam je naredio da pripremimo snage koliko smo u mogućnosti radi zastrašivanja neprijatelja. Uzvišeni je rekao: I protiv njih pripremite koliko god možete snage i konja za boj, da biste time zaplašili Allahove i vase neprijatelje, i druge osim njih - vi ih ne poznajete, Allah ih zna. Sve što na Allahovom putu potrosite, nadoknadeno će vam biti, neće vam se nepravda učiniti. (El-Enfal, 60.) Riječi Uzvišenog minel-kuvveti su općeg značenja i upućuju na sve putem čega se snaži i jača u ratu ma o čemu se radilo. ${ }^{47}$ Dakle, tu ulaze sve strategije, sredstva, naoružanja, vojne i ratne varke itd. Prema tome, ako mudžahidi od svega navedenog ne budu imali ništa drugo putem čega bi zastrašili svoje neprijatelje osim šehidskih akcija, one bi u tom slučaju imale status obligacije, a posebno kada se radi o odbrambenom džihadu čije odgađanje nije dozvoljeno.

\footnotetext{
${ }^{45}$ Ibnul-Kajjim, Zadul-mea'd, 3/505-506.

${ }^{46}$ Ebu-Ja'la, El-Ahkamus-sultanijje, str. 43., Maverdi, El-Ahkamus-sultanijje, str. 89.

${ }^{47}$ Ebu-Sau'd, Tefsir, 4/32.
} 
Sedmo: Ovakve akcije su nedvojbeno dale plodove i pribavile opću korist i postale su strah i trepet za sve okupatore i uzurpatore islamskih zemalja, prava i sloboda muslimana. One se smatraju šerijatskim sredstvima sa najmanjom štetom, a najdjelotvornijim učinkom. Mnoge studije su pokazale da su one bile glavni uzrok napuštanja islamskih zemalja od strane okupatora i umanjenja njihova useljavanja u njih. I ovo je jedan od najvećih dokaza da je njihova korist veća od štete.

\section{Umjesto zaključka}

Međutim, treba istaći da i pored toga što smo preferirali na osnovu navedenih dokaza da su šehidske akcije dozvoljene, ipak treba znati da ta dozvola nije općenita, nego je uslovljena sa slijedećim uvjetima: ${ }^{48}$

1. Da one donesu korist muslimanima, a gubitke neprijatelju. Dakle, ukoliko ne donesu interes islamu, a niti muslimanima, nego se fokusiraju samo na puko ubijanje nekoga, u tom slučaju to ne bi bilo dozvoljeno, osim ukoliko ne bi prevagnula korist nad interesom. Muhammed Šejbani je rekao: 'Ukoliko borac zna da im neće nanijeti stetu, onda mu nije dozvoljeno ni da se baca na njih, jer sa tim neće učiniti nikakvu korist vjeri osim što će izvršiti samoubistvo, a Uzvišeni je rekao: 'Ne ubijajte sami sebe. $^{49}$

2. Da se interes muslimana jedino i isključivo može postići na takav način, tj. da se ne mogu nanijeti štete neprijatelju, ili zaplašiti ga, ili ubiti one koji se trebaju ubiti, osim putem samoubilačkih napada. Prema tome, ovakve akcije se dozvoljavaju samo kad postanu jedino sredstvo za realizaciju namjeravanog interesa. Ukoliko je na neki drugi način moguće postići taj opći interes islama i muslimana, onda one postaju zabranjene;

3. Da one ne donesu veću štetu od koristi koja se očekuje od njih, jer se uklanjanju štete daje prednost nad pribavljanjem koristi, a u slučaju kada dođu u kontradiktornost uvažava se veća nauštrb manje;

\footnotetext{
48 A'tijje A'dlan, El-Ahkamuš-šeri'jjetu li en-navazil es-sijasijje, Darul-kutubil-masrijje, prvo izdanje, 2011., Kairo.

49 Šejbani, Es-Sijerul-kebirme'aš-Šerhi, od Serahsija, 1/164.
} 
4. Da glavni motiv tih akcija ne bude zastrašivanje civila, jer bi tada takve akcije imale status bježanja od umišljene štete kod koje je pohvalno iskazati strpljenje ka sigurnoj šteti, koju nije dozvoljeno počiniti bez opravdanog šerijatskog razloga;

5. Da se putem tih akcija ne namjeravaju uništiti oni koji nemaju direktne ili indirektne veze sa ratom i okupacijom;

6. Da se te akcije isključivo izvode na okupiranim islamskim zemljama protiv okupatora, tj. onih koji su ih okupirali;

7. Takve akcije nije dozvoljeno prenositi i izvoditi izvan granica okupirane zemlje, niti kažnjavati nedužne civile, kao ni uništavati imovinu ili interese onih s kojima imamo po Šerijatu legalno sklopljene mirovne ugovore koje smo dužni poštovati i ne kršiti ih. Ubijanje nedužnih i kršenje ugovora i preuzetih obaveza $u$ islamu smatraju se najvećim grijesima koje musliman ni u nuždi ne smije počiniti.

I na kraju, završimo ovu temu sa citatom dr. Karadavija koji je, govoreći o ovim akcijama, rekao: I sve što tražim ovdje je da se te akcije odobravaju $i$ izvode poslije podrobnog studiranja $i$ balansiranja njihovih koristi i steta. A to treba da se realizuje putem kolektivnog razmisljanja od strane najodgovornijih, najpovjerljivijih $i$ najstručnijih muslimana. Kada se uvjere da su one korisne i dobre, trebaju ih izvrsiti i osloniti se na Allaha: 'A onaj ko se u Allaha pouzda - pa, Allah je zaista silan i mudar' (El-Enfal, 49.). ${ }^{50}$

${ }^{50}$ Karadavi, Fetava Mua'sire, 3/510. 


\section{Literatura:}

1. A'tijje A'dlan, El-Ahkamuš-šeri'jjetu li en-navazil es-sijasijje, Darul-kutubilmasrijje, prvo izdanje, 2011., Kairo.

2. Bejheki, Es-Sunenul-kubra.

3. Bejheki, Šua'bul-imani.

4. Dželaludin Sujutu, El-Ešbahu ven-nezair.

5. El-U'sejmin, Šerhu Rijadis-salihin, Darul-iman, El-Mensure, Misr.

6. Ibn Ebi-Šejbe, El-Musannef,

7. Ibn-Hadžer, El-Isabe.

8. Ibn-Kesir, El-Bidajeven-nihaje.

9. Ibn-Kesir, Tefsirul-Kur'anil-a'zim.

10. Ibn-Kudame, El-Mugni.

11. Ibn-Nudžejm, El-Ešbahu ven-nezair.

12. Ibn-Tejmijje, Medžmu'ul-fetava.

13. Ibnul-Kajjim, Zadul-mea'd.

14. Jusuf Karadavi, Fetava Mua'sire.

15. Kurtubi, Tefsir.

16. Muhammed Ibrahim Ali Šejh, Fetava ve resail.

17. Nevvaf Hajil Tekruri, El-A'melijatul-istišhadije ve suveru ve vesaikulmukavemetil-lubnanijje, Darul-fikr, Damask, 4. izdanje, 2003. god.

18. Taberi, Tefsir. 
Sulejman Topoljak, PhD

\section{A MARTYRDOM (SUICIDE) ATTACKS IN THE LIGHT OF ISLAMIC TEACHINGS}

\section{Summary}

Any action inevitably leads to reaction. Maestro's of modern times have seized power and came to the throne of world governance in most cases through lies, deceit and injustice. On the way to achieve these privileges, they were not afraid to violate the rights of others, apply another injustice, humiliation, etc., and when it was necessary, they were not afraid to occupy someone else's country and expel or destroy all its inhabitants, and even entire nations. And what 's even worse than that is that the modern world has accepted this actions as normal and that these things are legalized and accepted by international organizations which are primarily established to establish justice and to stand on the side of the weak against bullies and to protect the world peace. Unfortunately, they took the side of the usurpers of others' rights and homelands, homes, thugs and kidnappers and instead of protecting buman rights, they started protecting the laws of the jungle.

It was inevitable that such unjust actions of the contemporary world will inevitably lead to different reactions, and one of them is the topic we want to write about and which we want to investigate in the light of Islamic teachings as the only realistic and objective criteria for what is now happening and taking place in a world full of hypocrisy, absurd and illogical things, injustice and falsehood. Therefore, this study will attempt to define and clarify the meaning of suicide bombings or martyrdom attacks, their forms, legal status, opinions of Islamic jurists about this phenomenon, a critical review of their evidence and the final Islamic judgement.

Keywords: Attacks, suicide, martyr, Mujahid, action, fighting, injustice, justice, evidence, opinion 


\section{الأستاذ الدكتور سليمان توبولياك}

\section{العمليات الاستشهادية (الانتحارية) في ضوء تعاليم الإسلام}

\section{الخلاصية}

كل فعل حتمياً يؤدي إلى ردة فعل. فنانو العصر الحاضر استولوا على السلطة

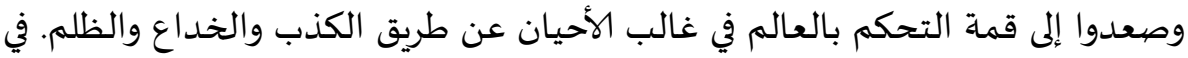

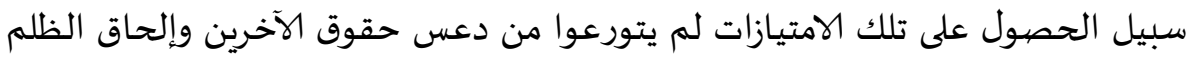

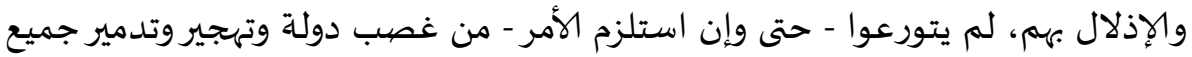

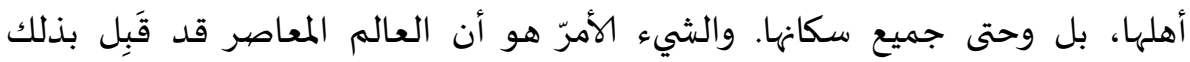

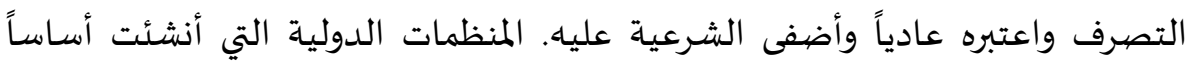

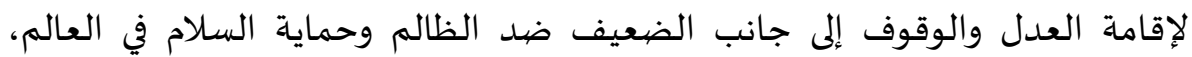

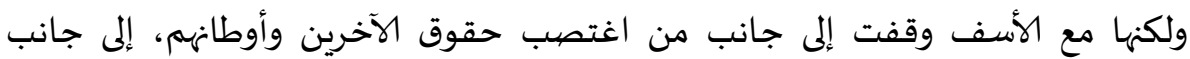

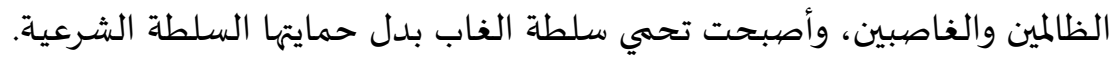

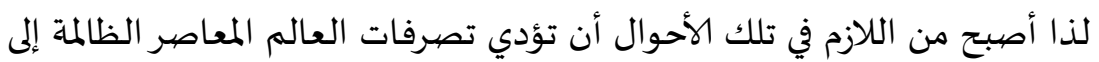

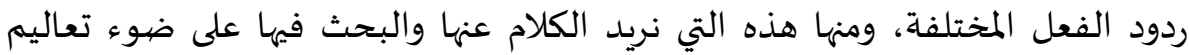

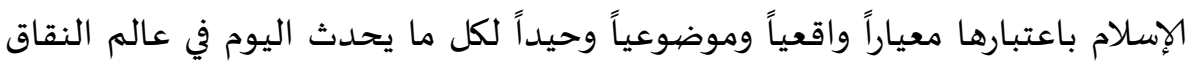

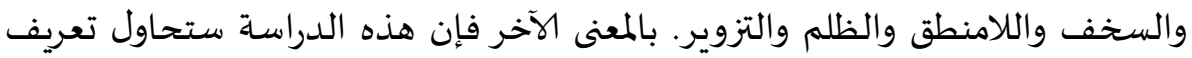
وشرح معنى العمليات الانتحارية أو الاستشهادية: صورها، حكمها والشها الشرعي، آراء الفقهاء في تلك الظاهرة، نقد تلك الآراء وحكم الإسلام النهائي.

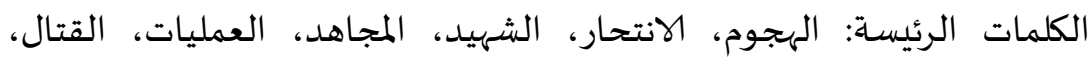

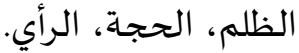

